\title{
SURVEI MINAT DAN HASIL BELAJAR SISWA DALAM MENGIKUTI PEMBELAJARAN SEMASA NEW NORMAL COVID-19 PADA KELAS V SEKOLAH DASAR
}

\author{
Syofia Alkhaira dan Mai Sri Lena \\ Jurusan Pendidikan Guru SD, Fakultas Ilmu Pendidikan, Universitas Negeri Padang \\ Email: sofiaalkhaira@gmail.com,maisrilena@fip.unp.ac.id
}

\begin{abstract}
Abstrak
Munculnya kebijakan new normal Covid-19 menjadikan harapan baru bagi masyarakat untuk melakukan berbagai aktivitas langsung terutama dibidang pendidikan, siswa yang sebelumnya melakukan kegiatan pembelajaran secara daring sekarang diberi kesempatan untuk kembali sekolah dengan mengikuti syarat dan ketentuan yang berlaku. Penelitian ini bertujuan untuk mendeskripsikan minat dan hasil belajar siswa dalam mengikuti pembelajaran semasa new normal Covid-19 pada kelas $V$ Sekolah Dasar. Jenis penelitian yang digunakan dalam penelitian ini yaitu kuantitatif deskriptif dengan metode survey, variabel yang digunakan adalah variabel terikat yaitu minat dan hasil belajar siswa dalam mengikuti pembelajaran semasa new normal Covid-19. Data yang diperoleh dianalisis menggunakan program Microsoft Excel dan SPSS 16, analisis yang digunakan yaitu analisis deskriptif persentase. Hasil penelitian menunjukkan bahwa minat dan hasil belajar siswa dalam mengikuti pembelajaran semasa new normal tergolong baik yaitu 64,91\% dengan kategorisasi sangat tinggi sedangkan hasil belajar nilainya cukup baik yaitu rata-rata 79,26\% dengan nilai KKM 70. Minat dipengaruhi oleh beberapa indikator minat seperti perasaan senang mencapai nilai paling tinggi $21,12 \%$, motivasi $18,88 \%$, harapan $18,61 \%$, perasaan tertarik $18,36 \%$, kebutuhan $11,69 \%$, serta perhatian $11,32 \%$. Dalam hal ini indikator yang paling mempengaruhi minat dan hasil belajar dalam mengikuti pembelajaran semasa new normal Covid-19 pada siswa adalah perasaan senang.
\end{abstract}

Kata Kunci: minat, hasil belajar, new normal, covid-19

\section{THE SURVEY OF INTEREST AND LEARNING OUTCOMES OF STUDENT IN FOLLOWING LESSONS DURING THE NEW NORMAL COVID-19 IN CLASS V ELEMENTARY SCHOOL}

\begin{abstract}
The emergence of the new normal Covid-19 policy createed new hopes for the community to carry out various activities, especially in the field of education. Students who previously joined online learning activities are now given the opportunity to return to school with following certain criterias. The aim of this study is to describe students' interest and learning outcomes in participating in learning during the new normal Covid-19 in elementary school grade $V$. The type of analysis of this research is descriptive quantitative with survey method, the variable used is the dependent variable, namely the interest and learning outcomes of students participating in learning, in Sei.Rotan Elementary School, East Pariaman District, Pariaman City, new normal Covid-19 class V. Using Microsoft Excel and SPSS 16 programs, the data was analyzed and percentage descriptive analysis was used. The results showed the interest and learning student outcomes in participating in learning during the new normal was classified as good, In the other words, $64.91 \%$ with quite high categorization, while the learning outcomes were very good, namely an average of $79.26 \%$ with a KKM score of 70 . Interests are influenced by several interest indicators, such as feelings of pleasure reaching the highest score of $21.12 \%, 18.88 \%$ motivation, $18.61 \%$ expectations, $18.36 \%$ feelings of interest, $11.69 \%$ and $11.32 \%$ attention needs. In this case, the indicators that most influence interest and learning outcomes in among students was happy feeling.
\end{abstract}


Survei Minat dan Hasil Belajar Siswa Dalam Mengikuti Pembelajaran Semasa New Normal Covid-19 Pada Kelas V Sekolah Dasar Proyeksi, Vol. 16 (1) 2021, 50-60

Keywords: interest, learning outcomes, new normal, covid-19

\section{Pendahuluan}

Pendidikan merupakan jembatan ilmu yang bertujuan untuk meningkatkan kualitas sumber daya manusia. Selain itu pendidikan juga mendorong dan memajukan manusia untuk dapat berkembang dalam segala aspek kehidupan, baik dalam bidang sosial, politik, ekonomi, maupun budaya. Untuk mencapai tujuan pendidikan tentu diperlukan usaha dalam meningkatkan minat siswa agar mengikuti pembelajaran sesuai dengan kurikulum yang ditetapkan. Dalam proses pendidikan berhasil atau tidaknya pendidikan itu tergantung kepada keinginan siswa dalam menjalaninya. Pernyataan ini didukung oleh pendapat Pidarta (dalam Hairina,2017) yang menyatakan bahwa tujuan pendidikan di Indonesia baik itu sekolah, perguruan tinggi maupun nasional mencakup tiga ranah perkembangan manusia yaitu afeksi, kognisi dan psikomotor, disamping itu peserta didik dibebaskan memilih bakat, minat dan kemampuannya masing-masing.

Minat juga memiliki pengaruh terhadap jalannya aktivitas belajar siswa, karena apabila pelajaran yang dipelajari memberikan perasaan tertarik dan menyenangkan maka siswa akan lebih interaktif dalam mengikuti pembelajaran sehingga apa yang dipelajari dapat diterima dan dipahami dengan baik. Pernyataan ini diperkuat dengan pendapat dejamarah (dalam Siagan, 2015) yang menyebutkan bahwa minat belajar cenderung menghasilkan prestasi yang tinggi, sebaliknya minat belajar rendah akan menghasilkan prestasi belajar yang rendah juga.

Menurut data yang disampaikan oleh Yurianto (2020) jumlah kasus COVID-19 di Indonesia mencapai lebih dari 81.668. Pemerintah menanggapi permasalahan pandemi Covid-19 dengan memberlakukan kebijakan pembatasan sosial berskala besar (PSBB) sebagai bentuk penanganan COVID-19 dengan menerbitkan Peraturan Pemerintah (PP) Nomor 21 Tahun 2020 dan Keputusan Presiden (Keppres) Nomor 11 Tahun 2020.

Berdasarkan hasil observasi yang peneliti lakukan pada siswa kelas $V$ di sekolah dasar Sei.Rotan Kota Pariaman pada tanggal 19 juni 2019 terdapat berbagai alasan yang peneliti dapatkan dari hasil observasi dan wawancara siswa diantaranya : 1) siswa malas mengerjakan tugas sekolah karena tugas yang diberikan secara online sangat banyak dan dikumpulkan sekali seminggu untuk semua mata pelajaran, 2) beberapa siswa sulit memahami pembelajaran yang dijelaskan guru melalui whatsapp, 3) beberapa siswa bosan karena belajar sendiri dan diawasi orang tua, 4) siswa mengeluh karena jaringan sering terganggu saat belajar, 5) siswa tidak semangat mengikuti pembelajaran.

Beberapa alasan di atas mempengaruhi menurunnya hasil belajar siswa, sebagaimana terlihat pada hasil ulangan harian matematika di sekolah dasar nagari sei.rotan kecamatan pariaman timur kota pariaman seperti yang ditunjukkan pada tabel dibawah ini :

Tabel 1. Nilai rata-rata hasil belajar siswa

\begin{tabular}{ccc}
\hline KKM & Nilai rata-rata & Jumlah Siswa Keseluruhan \\
\hline 70 & 65,4 & 25 \\
\hline Sumber : Wali kelas $V$ &
\end{tabular}

Mulainya era New normal di Indonesia mengembalikan kegiatan sekolah seperti sebelum pandemic namun tetap mengikuti protocol kesehatan seperti menggunakan masker, selalu cuci tangan, dan menjaga jarak. Hal ini terangkum dalam Keputusan Menteri. Kesehatan Nomor HK 
01.07/MENKES/328/2020. Kebijakan dalam menjalani new normal COVID-19 menjadi kekhawatiran bagi banyak orang dalam melakukan aktivitas yang bersifat publik akan terjangkitnya risiko virus corona. Namun hal ini tidak bisa dihindari, bagaimanapun kehidupan harus tetap dijalani agar perekonomian dan pendidikan tetap berlangsung.

Jika sebelumnya pembelajaran dilakukan dengan media online maka dimasa new normal ini siswa kembali melakukan pembelajaran di sekolah. Untuk aktivitas sekolah memiliki beberapa aturan waktu agar terhindar dari penyebaran virus corona, pembelajaran yang awalnya dilakukan sampai pukul 1.00 sekarang dilaksanakan sampai pukul 10.00 tanpa adanya waktu istirahat. Melihat permasalahan-permasalahan diatas menarik perhatian peneliti untuk mengetahui secara pasti minat dan hasil belajar siswa semasa new normal Covid-19 ini. Selain hal itu, penggunaan media belajar online tidak semua guru dapat menerapkannya begitupun dengan siswa ada cukup banyak keluhan karena pemberian tugas yang banyak disetiap mata pelajaran serta singkatnya waktu dalam pengerjaan. Keadaan ini juga dijelaskan oleh Chaterine (2020) bahwa penerapan kebijakan belajar di rumah membuat sebagian siswa merasa cemas dan tertekan, banyaknya tugas yang diberikan oleh guru membuat banyak siswa mengalami stress dan jenuh dalam menjalani pembelajaran daring.

Faktor lain yang menghambat pembelajaran online yaitu penggunaan jaringan internet yang berketerusan, jaringan yang tidak stabil, serta sulitnya bagi siswa untuk bertanya apabila tidak memahami pelajaran atau tugas yang diberikan. Dibukanya kembali sekolah memberi gambaran baru terhadap pembelajaran di masa new normal COVID-19, baik itu dari strategi guru dalam mengajar ataupun mengembangkan media yang membantu siswa dalam belajar, kesulitan belajar sebelumnya diharapkan dapat terpenuhi dimasa new normal COVID-19, sehingga minat siswa dalam mengikuti pembelajaran muncul dan hasil belajar meningkat dari sebelumnya.

\section{Metode Penelitian}

\section{Jenis Penelitian}

Jenis penelitian ini adalah kuantitatif deskriptif yaitu penelitian yang digunakan untuk membuat suatu kesimpulan utama dengan menganalisis dan menggambarkan hasil penelitian secara jelas (Sugiyono, 2012: 29).

\section{Waktu dan Tempat Penelitian}

Penelitian dijalankan di Sekolah Dasar Nagari Sei.Rotan Kecamatan Pariaman Timur Kota Pariaman. Pada awal bulan Agustus 2020.

\section{Target/ Subjek penelitian}

Populasi pada penelitian ini yaitu seluruh kelas V Sekolah Dasar Nagari Sei. Rotan, Kecamatan Pariaman, Timur Kota Pariaman. 
Tabel 2. Siswa Kelas V SD Nagari Kp. Kandang Pariaman Timur

\begin{tabular}{crcc}
\hline No & \multicolumn{1}{c}{ Sekolah } & Kelas & Jumlah \\
\hline 1. & SDN 03 Bungo Tanjuang & V & 14 Siswa \\
2. & SDN 13 Kampuang Kandang & V & 9 Siswa \\
3. & SDN 04 Kajai & V & 13 Siswa \\
4. & SDN 12 Cubadak Mentawai & VA & 10 Siswa \\
& & VB & 11 Siswa \\
& JUMLAH & & 57 Siswa \\
\hline
\end{tabular}

Sumber : Wali kelas V SD Nagari Sei.Rotan Kecamatan Pariaman Timur Kota Pariaman

Teknik pengambilan sampel pada penelitian ini menggunakan total sampling. Total sampling merupakan suatu cara yang ditempuh dengan pengambilan sampel yang benar-benar sesuai dengan keseluruhan objek penelitian (Nursalam, 2008). Apabila jumlah populasi kurang dari 100 maka peneliti dapat mengambil sampel dari keseluruhan populasi hal ini disebut penelitian populasi atau total sampling (Arikunto, 2006 :134).

\section{Teknik Pengumpulan Data}

Penelitian ini menggunakan instrumen berupa angket/kuesioner. Penyusunan instrumen berupa angket diawali dengan menyusun indikator soal, kemudian menyusun butir angket, setelahnya dilakukan uji coba menggunakan alat pengumpulan data untuk dihitung reliabilitas dan validitasnya. Indikator soal pada kuesioner diadaptasi dari beberapa penelitian kemudian dikonsultasikan dengan pembimbing dengan beberapa kali revisi, setelah itu langsung dilakukan uji coba. Terdapat 6 indikator yang digunakan dalam penyusunan kuesioner diantaranya perasaan tertarik, perhatian, perasaan senang, kebutuhan, harapan dan motivasi. Isi kuesioner berjumlah 17 soal pertanyaan dengan 5 pilihan skala. Pilihan skala ini memiliki tingkatan mulai dari Sangat Setuju(SS), Setuju(S), Ragu-Ragu(RR), Tidak Setuju(TS), hingga Sangat Tidak Setuju(STS). Penelitian yang mengukur sikap dan pendapat dapat menggunakan skala Likert. Sebelum penelitian dilakukan peneliti melakukan uji coba terhadap angket yang akan di sebarkan, diantara uji coba yang dipakai adalah uji validitas dan uji reliabilitas. Uji coba ini dilakukan menggunakan program SPSS Windows 16.

\section{Teknik Analisis Data}

Penelitian ini dianalisis menggunakan teknik statistic deskriptif dengan melihat skor rata-rata dan persentasenya.

\section{Hasil dan Pembahasan}

\section{Hasil Data Minat Belajar Siswa}

Populasi penelitian berjumlah 57 siswa, diantaranya 21 siswa SDN 12 Cubadak mentawai, 14 siswa SDN 03 Bungo Tanjuang, 9 siswa SDN 13 Kampung Kandang, dan 13 siswa SDN 04Kajai. Jumlah ini ditunjukkan pada tabel berikut: 
Tabel 3. Hasil Presentase Subjek Berdasarkan Jenis Kelamin

\begin{tabular}{|c|c|c|}
\hline Jenis Kelamin & Frekuensi & Presentase \\
\hline Perempuan & 28 Orang & $49,12 \%$ \\
\hline Laki-Laki & 29 Orang & $50,88 \%$ \\
\hline Total & 57 Orang & $100 \%$ \\
\hline
\end{tabular}

Hasil presentasi data diatas, menunjukkan subjek penelitian dengan jenis kelamin perempuan lebih banyak yaitu sebanyak 29 Orang $(50,88 \%)$ dan laki-laki terdapat 28 orang $(49,12 \%)$. Perbandingan jenis kelamin pada subjek penelitian dapat dikategorikan seimbang karena hanya selisih satu orang.

Tabel 4. Hasil Angket Minat Siswa

\begin{tabular}{|c|c|c|c|c|c|c|c|}
\hline V & $x-\min$ & $x-\max$ & $-x$ & Me & Mo & $\sigma 2$ & SD \\
\hline$x$ & 54 & 85 & 70,39 & 71 & 74 & 49,10 & 7,01 \\
\hline
\end{tabular}

Perolehan data pada tabel diatas dapat diartikan bahwa skor minimum dari angket minat belajar siswa sekolah dasar semasa "New normal" Covid-19 sebesar 54, skor maksimal sebesar 85, mean (rata-rata) skor angket sebesar 70,39, Median yang diperoleh sebesar 71, Modus yang didapat sebesar 74, variansnya sebesar 49,10 dan standar deviasi sebesar 7,01.

Hasil skor persentase indikator minat belajar siswa ditunjukkan pada tabel dibawah ini:

Tabel 5. Tingkat presentase minat belajar siswa

\begin{tabular}{clc}
\hline No & \multicolumn{1}{c}{ Faktor Minat Belajar } & Presentase \\
\hline 1. & Perasaan Senang & $21,12 \%$ \\
2. & Motivasi & $18,88 \%$ \\
3. & Harapan & $18,61 \%$ \\
4. & Perasaan Tertarik & $18,36 \%$ \\
5. & Kebutuhan & $11,69 \%$ \\
6. & Perhatian & $11,32 \%$ \\
\hline
\end{tabular}

Berdasarkan persentase dari masing-masing indikator dapat dilihat bahwa minat belajar paling tinggi yaitu perasaan senang dengan hasil skor persentasenya sebesar $(21,12 \%)$, kemudian ada motivasi. Motivasi berada pada urutan kedua setelah perasaan senang, berdasarkan perolehan hasil skor persentasenya motivasi menjadi salah satu faktor minat belajar yang skornya cukup tinggi yaitu sebesar (18,88\%). Ketiga terdapat harapan dengan hasil skor persentasenya sebesar $(18,61 \%)$, keempat adanya perasaan tertarik dengan hasil skor persentase sebesar $(18,36 \%)$, kelima adanya kebutuhan dengan hasil skor persentase sebesar $(11,69 \%)$, serta yang terakhir adanya perhatian dengan hasil skor persentase sebesar (11,32\%). 
Tabel 6. Kategorisasi Minat Belajar Siswa

\begin{tabular}{ccccc}
\hline Perhitungan Skor & Rentang Skor & Jumlah Subjek & Persentase & Kategorisasi \\
\hline $\mathrm{X}$ item $\leq \mathrm{x} 1,5 \sigma$ & $>68$ & 37 & $64,91 \%$ & Sangat Tinggi \\
$\mathrm{x}+0,5 \sigma<\mathrm{X}$ item $\leq \mathrm{x}+1,5 \sigma$ & $57-68$ & 18 & $31,58 \%$ & Tinggi \\
$\mathrm{x}-0,5 \sigma<\mathrm{X}$ item $\leq \mathrm{x}+0,5 \sigma$ & $45-57$ & 2 & $3,51 \%$ & Sedang \\
$\mathrm{x}-1,5 \sigma<\mathrm{X}$ item $\leq \mathrm{x}-0,5 \sigma$ & $34-45$ & 0 & $0 \%$ & Rendah \\
$\mathrm{x}-1,5 \sigma \leq \mathrm{X}$ item & $<34$ & 0 & $0 \%$ & Sangat Rendah \\
\hline
\end{tabular}

Sumber : Azwar (2010)

Berdasarkan hasil kategorisasi minat belajar siswa pada tabel diatas dapat disimpulkan bahwa dari 57 jumlah siswa terdapat 37 siswa yang memperoleh skor 68 dengan hasil persentase 64,91\% jumlah ini termasuk dalam kategorisasi sangat tinggi. Untuk hasil persentase terendah itu berada pada rentang 45-57 dengan jumlah siswa 2 orang. Dalam hal ini dapat kita lihat jumlah siswa yang memiliki minat dalam mengikuti pembelajaran dimasa new normal lebih banyak dari yang kurang berminat.

\section{Hasil Data dari Hasil Belajar Siswa}

Data hasil belajar siswa diperoleh berdasarkan nilai Akhir Semester 1 pada mata pelajaran matematika. skor terkait hasil belajar siswa semasa "New normal" Covid-19 tercantum pada tabel di bawah ini:

Tabel 3.5 Hasil data dari Hasil Belajar

\begin{tabular}{cccccccc}
\hline $\mathbf{v}$ & $\mathbf{x}-\min$ & $\mathbf{x}-\max$ & $-\mathbf{x}$ & Me & Mo & $\boldsymbol{\sigma 2}$ & SD \\
\hline $\mathrm{X}$ & 70 & 91 & 79,26 & 79 & 74 & 32,77 & 5,72 \\
\hline
\end{tabular}

Berdasarkan tabel diatas dapat dilihat bahwa skor minimum dari hasil belajar siswa yaitu sebesar 70, terdapat 2 orang siswa memperoleh skor minimum ini, sedangkan skor maksimum yang diperoleh satu orang siswa yaitu sebesar 91. Skor rata-rata (mean) dari data hasil belajar siswa mencapai angka sebesar 79,26, skor median pada data hasil belajar siswa ini yaitu 79 sedangkan skor modusnya sebesar 74 dan standar deviasi dari data ini berjumlah 5,72. Skor yang dipaparkan ini diperoleh dari data yang diolah berdasarkan hasil belajar siswa dalam pembelajaran matematika semasa "New normal" Covid-19, hasilnya cukup baik dengan rata-rata 79,26. Nilai KKM untuk pembelajaran matematika adalah 70 .

\section{Pembahasan}

\section{Minat Belajar Siswa}

Berdasarkan tingkat kategorisasi minat belajar siswa diketahui $64,91 \%$ siswa berada dalam kategorisasi sangat tinggi, 31,58\% dengan kategorisasi tinggi, 3,51\% dengan kategorisasi sedang. Adapun persentase dari masing-masing indikator minat siswa adalah sebagai berikut : perasaan senang $(21,12 \%)$, motivasi $(18,88 \%)$, harapan $(18,61 \%)$, perasaan tertarik $(18,36 \%)$, kebutuhan $(11,69 \%)$, dan 
perhatian (11,32\%). Keenam faktor ini berperan penting dalam minat siswa. Faktor minat belajar yang dominan dari jawaban siswa pada kuesioner yaitu perasaan senang dimana dalam keadaan apapun apabila anak merasa senang maka pembelajaran yang diikuti akan mudah dipahami. Marimba (dalam Ricardo, 2017) menyatakan bahwa perasaan senang umumnya ditandai dengan adanya kecenderungan jiwa untuk mendapat sesuatu karena adanya hal yang menarik didalamnya. Dari hasil penelitian yang diperoleh dapat dikatakan bahwa minat belajar siswa semasa new normal Covid-19 pada kelas v Sekolah Dasar Nagari Sei.Rotan Kecamatan Pariaman Timur Kota Pariaman sebagian besar sangat tinggi. Berikut adalah penjelasan dari hasil persentase pada masing-masing indikator:

1. Perasaan senang memiliki persentase paling tinggi yaitu $21,12 \%$. Menurut W.S Winkel (dalam Prasetya, 2019: 168) "kecenderungan subjek untuk menetap pada suatu bidang studi itu karena merasa senang mempelajari materi itu". Untuk dapat menjamin hasil belajar baik, maka siswa harus memiliki mood atau perasaan senang baik itu terhadap keadaan belajar, metode belajar ataupun senang terhadap pelajaran itu sendiri. Perasaan senang belajar semasa new normal Covid-19 pada kelas V Sekolah Dasar Nagari Sei.Rotan Kota Pariaman tergolong tinggi, tapi masih perlunya peningkatan karena situasi Covid-19 ini perlunya peningkatan dalam melaksanakan pembelajaran sehingga siswa selalu senang belajar walaupun keadaan yang mengkhawatirkan saat ini misalnya dengan memperbarui cara atau strategi dalam melaksanakan pembelajaran agar tidak membosankan.

2. Indikator terakhir yaitu motivasi dengan skor hasil perhitungan yang cukup tinggi yaitu sebesar 18, $88 \%$. Khodijah (dalam Fauziah, 2017) menjelaskan bahwa motivasi belajar merupakan kondisi yang mendorong diri seseorang untuk mempelajari sesuatu. Hasil perhitungan peserta didik di kelas $\mathrm{V}$ Sekolah Dasar Nagari Sei.Rotan Kota Pariaman memiliki motivasi yang tinggi dalam mengikuti pembelajaran semasa new normal Covid-19, namun juga ada siswa yang motivasinya rendah dalam mengikuti aktivitas belajar semasa new normal Covid-19 karena lebih memilih belajar online.

3. Selanjutnya terdapat indikator harapan dengan hasil perhitungan sebesar $18,61 \%$. Menurut Edwards (dalam widiarti, 2013) harapan merupakan keadaan motivasional yang memiliki tujuan, jalan dan wakil dari pemikiran yang berorientasi pada cita-cita. Siswa kelas V Sekolah Dasar Nagari Sei.Rotan Kota Pariaman memiliki harapan tinggi dalam pelaksanaan pembelajaran semasa new normal Covid-19 yaitu dibukanya kembali sekolah, namun beberapa siswa lebih memilih belajar dirumah karena lebih aman.

4. Indikator selanjutnya yaitu perasaan tertarik, pada penelitian ini hasil perhitungan yang diperoleh yaitu sebesar 18,36\%. Berdasarkan Depdiknas (dalam KBBI, 2002) menyatakan bahwa perasaan tertarik merupakan perasaan lega, suka, dan gembira. Perasaan tertarik ini merupakan sikap positif terhadap aktivitas belajar karena akan menjadikan minat siswa belajar meningkat. Peserta didik kelas V Sekolah Dasar Sei.Rotan Kota Pariaman memiliki perasaan tertarik cukup tinggi dalam minat belajar semasa new normal Covid-19, namun terdapat beberapa siswa yang kurangnya perasaan tertarik dalam mengikuti pembelajaran semasa new normal Covid-19 karena lebih menyukai belajar secara online.

5. Indikator selanjutnya yaitu kebutuhan dimana hasil perhitungan yang diperoleh sebesar $11,69 \%$. Menurut Slameto (dalam Fauziah, 2017) menyebutkan bahwa intensitas kebutuhan seseorang secara signifikan terhadap besarnya minat individu yang bersangkutan. Berdasarkan hasil survey peserta didik pada kelas V Sekolah Dasar Nagari Sei.Rotan Kota Pariaman terkategori memiliki 
minat belajar semasa new normal Covid-19 yang rendah, kebutuhan pada peningkatan minat yang dituju yaitu penggunaan media belajar di sekolah, oleh karena itu sebagian siswa semasa new normal Covid-19 kurangnya minat dalam hal penggunaan media belajar sehingga siswa tidak menggunakannya atau membutuhkannya. Hal ini juga bisa dijadikan perbaikan untuk mengembangkan media belajar sekolah sehingga siswa merasa membutuhkannnya untuk menunjang pembelajaran.

6. Indikator kedua yaitu perhatian memiliki hasil perhitungan persentase paling rendah dari indikator yang lainnya yaitu $11,32 \%$. Perhatian diartikan sebagai bentuk fokus siswa dalam mengamati dan mengartikan suatu hal tanpa memperdulikan hal lainnya. Siswa kelas V Sekolah Dasar Nagari Sei.Rotan pada dasarnya sudah fokus dalam mengamati suatu hal, namun terdapat siswa yang terkendala karena beberapa alasan seperti saat kondisi Covid-19 ini seperti siswa yang harus membantu orangtua menghasilkan uang dengan mempersiapkan makanan jajan untuk dijual disekolah sehingga saat proses belajar saat proses belajar kurangnya konsentrasi dan mengantuk saat belajar siang.

\section{Hasil Belajar Siswa}

Hasil perhitungan hasil belajar semasa new normal Covid-19 siswa kelas V Nagari Sei.Rotan Kecamatan Kota Pariaman terbilang cukup baik, skor ini diperoleh dari data yang diolah berdasarkan nilai akhir siswa dalam bidang studi matematika yaitu dengan skor rata-rata sebesar 79,26. KKM yang ditetap sekolah untuk pembelajaran matematika yaitu 70 maka dengan hasil skor yang diperoleh siswa cukup baik menjalankan pembelajaran semasa new normal Covid-19.

\section{Kesimpulan}

Berdasarkan perolehan data hasil penelitian serta deskripsinya dapat peneliti simpulkan sebagai berikut: (1) Persentase minat siswa dalam mengikuti pembelajaran semasa new normal Covid19 pada siswa kelas v Sekolah Dasar Nagari Sei. Rotan, Kecamatan Pariaman Timur, Kota Pariaman sebesar 64,91\%dalam kategori sangat tinggi, (2) Persentase masing-masing indikator yang mempengaruhi minat siswa dalam mengikuti pembelajaran semasa new normal Covid-19 pada siswa kelas V Sekolah Dasar Nagari Sei.Rotan Kecamatan Pariaman Timur Kota Pariaman pada umumnya dalam kategori sedang dengan persentase perasaan senang $21,12 \%$, perhatian $11,32 \%$, harapan $18,61 \%$, perasaan tertarik $18,36 \%$, kebutuhan $11,69 \%$ dan motivasi $18,88 \%$. Hasil pengolahan data menunjukkan minat belajar siswa didominasi oleh faktor perasaan senang dengan persentase $21,12 \%$. Adanya penelitian ini memberikan gambaran bahwa menjalani kegiatan pembelajaran semasa new normal Covid-19 memiliki pengaruh pada keinginan siswa dalam belajar hal ini juga ditunjukkan dari hasil belajar siswa. Dari penelitian ini juga disimpulkan bahwa minat siswa berpengaruh pada siswa yang melakukan pembelajaran langsung dengan guru dibandingkan secara online, namun selama siswa masih memiliki keinginan untuk belajar maka siswa tersebut dapat mencapainya dengan baik bagaimanapun keadaan disekitarnya. 


\section{Daftar Pustaka}

Andri, A., \& Rismawati, M. (2018). Analisis Faktor-faktor yang mempengaruhi rendahnya hasil belajar konsep dasar matematika SD Pada Mahasiswa PGSD. Vox Edukasi, 9(2), 271432.

Ambarwati, S., Suroso, S., \& Yustinus, Y. (2018). Meningkatkan Hasil Belajar Dan Minat Baca Pada Mupel Ipa Menggunakan Metode Survey, Question, Read, Recite Pada Kelas 5 Sd. Pendekar: Jurnal Pendidikan Berkarakter, 1(1), 292-302.

Arikunto, S. (2005). Manajemen Penelitian. Jakarta: Rineka Cipta.

Arikunto, Suharsimi. 2006. Prosedur Penelitian Suatu Praktek. Jakarta: Rineka Cipta.

Aritonang, K. T. (2008). Minat dan motivasi dalam meningkatkan hasil belajar siswa. Jurnal pendidikan penabur, $7(10), 11-21$.

Azwar, S. (2007). Dasar-Dasar Psikometri. (Edisi 1). Yogyakarta: Pustaka Pelajar.

Azwar, S. (2010). Penyusunan Skala Psikologi. Yogyakarta: Pustaka Pelajar.

Bimo Walgito. 1997. Pengantar Psikologi Umum. Yogyakarta: Pustaka Pelajar.

Boimau, D. Y. I. (2017). Peranan Guru Dalam Menanamkan Minat Belajar Peserta Didik Di Sd Nagari Upunkoi Soe Timor Tengah Selatan (Doctoral Dissertation, Sekolah Tinggi Teologi Injili Arastamar (Setia) Jakarta).

Bumulo, R. (2015). Faktor-Faktor yang Mempengaruhi Minat Belajar Siswa pada Pelajaran IPA di Kelas V SDN 1 Tapa Kabupaten Bone Bolango. Skripsi, 1(151411145).

Chaterine, R. N. (2020, March 18). Siswa belajar dari rumah, KPAl: Anak-anak stres dikasih banyak tugas. Detik News. Retrieved from https://news.detik.com/berita/d-4944071/siswabelajar-darirumah-kpai-anak-anak-stres-dikasihbanyak-tugas

dr. Meva Nareza. 2020. Di akses di https://www.alodokter.com/ini-panduan-menjalani-new-normalsaat-pandemi-corona pada tanggal 04 Juni 2020

Fauziah, A., Rosnaningsih, A., \& Azhar, S. (2017). Hubungan antara motivasi belajar dengan minat belajar siswa kelas IV SDN Poris Gaga 05 kota Tangerang. Jurnal JPSD, 4(1), 47-53.

Fitriyani, Y., Fauzi, I., \& Sari, M. Z. (2020). Motivasi Belajar Mahasiswa Pada Pembelajaran Daring Selama Pandemik Covid-19. Jurnal Kependidikan: Jurnal Hasil Penelitian dan Kajian Kepustakaan di Bidang Pendidikan, Pengajaran dan Pembelajaran, 6(2), 165-175.

Hadis, Abdul dan Nurhayati B. 2010. Psikologi Dalam Pendidikan. Bandung: Cv Alpabeta.

Jamaluddin, D., Ratnasih, T., Gunawan, H., \& Paujiah, E. (2020). Pembelajaran daring masa pandemik Covid-19 pada calon guru: hambatan, solusi dan proyeksi. LP2M.

Kasandrawali, A. (2019). Survei Minat Olahraga Sepaktakaw Pada Siswa Sd Nagari 20/3 Tonasa Kecamatan Labbakang Kabupaten Pangkep. Riyadhoh: Jurnal Pendidikan Olahraga, 2(2), 50-59. 
Survei Minat dan Hasil Belajar Siswa Dalam Mengikuti Pembelajaran Semasa New Normal Covid-19 Pada Kelas V Sekolah Dasar Proyeksi, Vol. 16 (1) 2021, 50-60

Keputusan Menteri Kesehatan Nomor HK.01.07/MENKES/328/2020. Jakarta.

Kompasian.com. (2020). Memahami Istilah New normal. Diakses pada laman https://www.kompasiana.com/hpinstitute/5ead17b5d541df3e62051864/memahami-istilahnew-normal pada tanggal 03 Juni 2020

Marsuki, A. (2017). Survei Tingkat Kebugaran Jasmani Dan Minat Belajar Terhadap Prestasi Hasil Belajar Pendidikan Jasmani Siswa Sekolah Dasar Kabupaten Bone. In Susunan Redaksi Seminar Nasional "Tellu Cappa" (p. 92).

Morgan, H. (2020). Best Practices for Implementing Remote Learning during a Pandemic. The Clearing House: A Journal of Educational Strategies, Issues and Ideas, 93(3), 134-140.

MUFARIKHAH UMAR, L. U. L. U. S., \& Nursalim, M. (2020). Studi Kepustakaan Tentang Dampak Wabah Covid-19 Terhadap Kegiatan Belajar Mengajar Pada Siswa Sekolah Dasar (Sd). Jurnal BK UNESA, 11(4).

Muhyiddin, M., \& Nugroho, H. (2020). Edisi Khusus tentang Covid-19, New normal, dan Perencanaan Pembangunan. The Indonesian Journal of Development Planning, 4(2).

Novita, R., Supriatna, E., \& Puspitawati, I. D. (2013). Survei Minat Siswa-siswi dalam Pembelajaran Penjas di SMP Nagari 3 Samalantan (Doctoral dissertation, Tanjungpura University).

Oktawirawan, D. H. (2020). Faktor Pemicu Kecemasan Siswa dalam Melakukan Pembelajaran Daring di Masa Pandemi Covid-19. Jurnal Ilmiah Universitas Batanghari Jambi, 20(2), 541-544.

Padli, F., \& Rusdi, R. (2020). Respon Siswa Dalam Pembelajaran Online Selama Pandemi. Social Landscape Journal, 1(3), 1-7.

Peraturan Pemerintah Nomor 21 Tahun 2020 penanganan COVID-19. Jakarta.

Pingge, H. D., \& Wangid, M. N. (2016). Faktor yang mempengaruhi hasil belajar siswa sekolah dasar di kecamatan kota Tambolaka. Jurnal Pendidikan Sekolah Dasar Ahmad Dahlan, 2(1), 107-122.

Piyana, S. O. (2020). Identifikasi Kegiatan Belajar Siswa Ditinjau dari Minat dan Motivasi di Sekolah Dasar. LITERASI (Jurnal Ilmu Pendidikan), 11(1), 57-62.

Prasetiya, B. (2019). Analisis Studi Korelasional Kecerdasan Emosional dan Minat Belajar dengan Hasil Belajar Pendidikan Agama Islam. AL-MURABBI, 5(2), 165-184.

Pribowo, F. S. P. (2020, May). Persepsi Guru Sd Muhammadiyah Terhadap Penggunaan Gawai Dalam Pembelajaran Di Kelas. In Proceeding.

RAHADI, S. (2013). Minat Siswa Sekolah Dasar terhadap Bolavoli Mini (Survei pada Siswa Kelas V Sdn Se-kota Blitar). Jurnal Prestasi Olahraga, 1(1).

Raharjo, D. B., \& Sari, R. R. N. (2020, March 19). Belajar online di tengah corona, ada siswa mengeluh tensi darah naik. Suara. Retrieved from https://www.suara.com/news/2020/03/19/205940/ belajar-online-di-tengah-corona-ada-siswamengeluh-tensi-darah-naik. 
RI, B. K. D., Lt, G. N. I., \& Subroto, J. J. G. (2020). Tantangan pelaksanaan kebijakan belajar dari rumah dalam masa darurat Covid-19.

Ricardo, R., \& Meilani, R. I. (2017). Impak minat dan motivasi belajar terhadap hasil belajar siswa. Jurnal Pendidikan Manajemen Perkantoran (JPManper), 2(2), 188-201.

Riwahyudin, A. (2015). Pengaruh Sikap Siswa dan Minat Belajar Siswa Terhadap Hasil Belajar IPA Siswa Kelas V Sekolah Dasar Di Kabupaten Lamandau. Jurnal pendidikan dasar, 6(1), 11-23.

Saleh, M. S., \& Malinta, S. S. (2020). Survei Minat Belajar Siswa Dalam Mengikuti Pembelajaran Pendidikan Jasmani Di Smpn 30 Makassar. Kinestetik: Jurnal IImiah Pendidikan Jasmani, 4(1), 5562.

Simanjuntak, S. Y., \& Kismartini, K. (2020). Respon Pendidikan Dasar Terhadap Kebijakan Pembelajaran Jarak Jauh Selama Pandemi Covid-19 di Jawa Tengah. Jurnal IImiah Wahana Pendidikan, 6(3), 308316.

Simbolon, N. (2014). Faktor-faktor yang mempengaruhi minat belajar peserta didik. Elementary School Journal Pgsd Fip Unimed, 1(2).

Slameto. 2010. Belajar dan faktor-faktor yang mempengaruhinya, Jakarta: Rineka Cipta.

Sugihartono, dkk. 2007. Psikologi Pendidikan. Yogyakarta: UNY Press.

Sugiyono. 2011. Metode Penelitian Pendidikan Pendekatan Kuantitatif, Kualitatif dan R\&D. Bandung: Alfabeta.

Suharsimi. Arikunto, 1998. Prosedur Penelitian. Jakarta : Ghalia Indonesia.

Sundari, R. T. (2019). Pengaruh Sikap Percaya Diri Terhadap Hasil Belajar Siswa (Penelitian Survei di Kelas V Sekolah Dasar Wilayah Desa Cicalengka Wetan Kecamatan Cicalengka Kabupaten Bandung) (Doctoral dissertation, FKIP UNPAS).

Sujanto, Agus. 2009. Psikologi Umum. Jakarta: Bumi Aksara.

The Lexico Webster Dictionary. (2020) USA: The English Language Institue of America.

Tiurma, L., \& Retnawati, H. (2014). Keefektifan pembelajaran multimedia materi dimensi tiga ditinjau dari prestasi dan minat belajar matematika di SMA. Jurnal Kependidikan: Penelitian Inovasi Pembelajaran, 44(2).

Widiarti, I. S., Indrawati, E. S., \& Desiningrum, D. R. (2013). Coping Stres Pada Pengangguran Tenaga Kerja Terdidik. Empati, 2(4), 217-226. 